\title{
A practical technique for preserving specimens of duckmeal, Wolffia (Araceae)
}

\author{
Daniel F. Brunton \\ 216 Lincoln Heights Roads, Ottawa, Ontario KIA 8A8; email: bruntonconsulting@rogers.com
}

Brunton, D.F. 2019. A practical technique for preserving specimens of duckmeal, Wolffia (Araceae). Canadian Field-Naturalist 133(2): 139-143. https://doi.org/10.22621/cfn.v133i2.2108

\begin{abstract}
Making identifiable herbarium vouchers of the minute aquatic vascular plant duckmeal, Wolffia (Lemnoideae; Araceae) has typically required plants to be preserved in transparent, space-consuming vials that are fragile, difficult to work with, and labourious to prepare. An alternative technique for dry-mounting Wolffia within a layer of transparent, acid-free glue presents a promising alternative. Although the largely water-filled individual plants still compress substantially, this preparation technique results in specimens that retain their colour, size, and, most important, their shape. This greatly enhances the possibility of confident identification and simplifies both specimen preparation and storage.
\end{abstract}

Key words: Wolffia; Lemnoideae; Araceae; herbarium specimen preparation; storage

\section{Introduction}

Dore (1957) described the difficulty collectors face in securing voucher specimens of duckmeal (Wolffia spp., Lemnoideae, Araceae; also known as watermeal) in a condition that permits their re-examination and identification. Three species of this minute, simple plant, which is uncommon to rare throughout most of its Canadian range, typically form dense, floating mats (Figure 1) consisting of thousands and even millions of individuals (Brunton 2018; Brunton and Bickerton 2018). At least two Wolffia species (Figure 2) are native in southern Ontario and Quebec (Crow and Hellquist 2000). Individuals of this, the smallest flowering plant in the world, shrivel up into greenishbrown dust when air dried as conventional vascular plant herbarium specimens (Figure 3). This deformation eliminates the possibility of further identification, which is heavily dependent on plant shape characteristics (Crow and Hellquist 2000). Accordingly, the potential use of such material for taxonomic or phytogeographic analysis is substantially reduced.

Dore's (1957) solution to that curatorial challenge was to place Wolffia samples in a preservative fluid (alcohol) in a sealed glass vial, which was then attached to a standard herbarium sheet. Although this technique permits the voucher plants to retain their shape and size, it is an involved process that results in a slurry of colourless plants floating in a cumbersome, fragile vessel that takes up considerable space in a conventional herbarium arrangement. Individual plants also move freely within the vial and are difficult to follow or relocate. Unless the vial is opened (necessitating repetition of the entire voucher preparation process), the view of individual plants is also obscured and distorted by the glass container. There is a risk of breakage or leakage of the vials, as is evident in Dore's collection preserved in the Agriculture and Agri-Food Canada herbarium (DAO). In addition, the alcohol-filled vials are sealed with a flame or heat, a process that requires some experience and poses potential hazards (P.M. Catling pers. comm. 14 March 2019). Although preferable to simply drying plants into an unrecognizable condition, the vial solution is a cumbersome and unsatisfying curatorial response.

The easy availability of high-quality digital imagery in the field now provides a practical enhancement of the traditional air-dried voucher technique, because hard-copy images of fresh (pre-dried) voucher material can be affixed to the voucher sheet. However, photographs are only two-dimensional representations and cannot be used for detailed morphological studies.

Discussions with numerous field botanists in eastern Canada have confirmed that the difficulty in securing reasonable quality Wolffia vouchers significantly discourages their collection. This represents a floristic and conservation problem in Ontario and Quebec where Northern Duckmeal (Wolffia borealis (Engelmann) Landolt \& Wildi ex Gandhi, Wiersema $\&$ Brouillet) (= Wolffia punctata Grisebach) and Co-

$\overline{\text { A contribution }}$ towards the cost of this publication has been provided by the Thomas Manning Memorial Fund of the Ottawa Field-Naturalists' Club. 


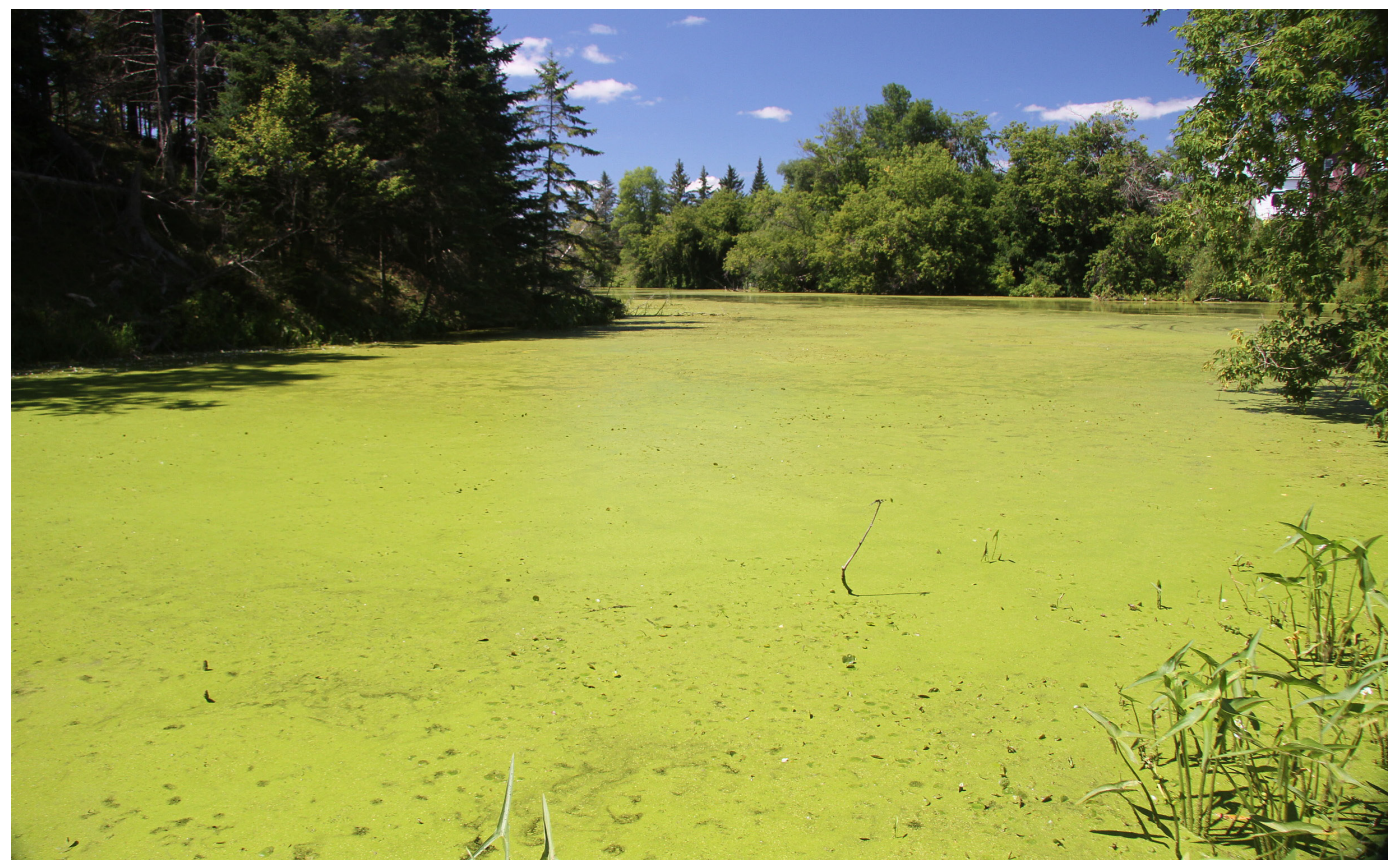

Figure 1. Dense duckmeal (Wolffia spp.) mat completely covering creek surface. 8 August 2011, Beachburg, Renfrew County, Ontario. Photo: D.F. Brunton.

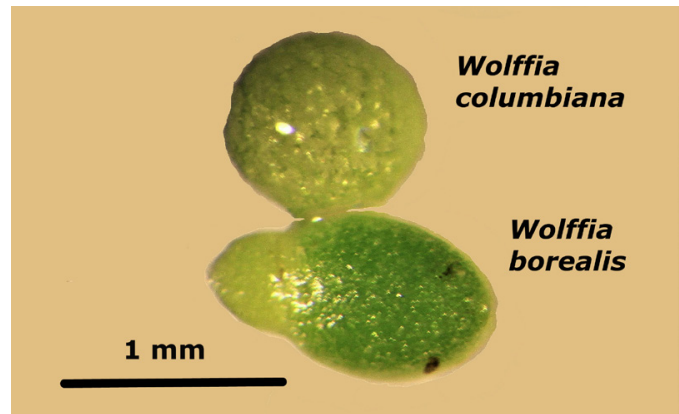

Figure 2. Fresh (live) Ontario native duckmeal (Wolffia) species. 31 July 2011, Peterborough County, Ontario, D.F. Brunton \& K.L. McIntosh 17,896B. Photo: D.F. Brunton.

lumbia Duckmeal (Wolffia columbiana H. Kirsten) (= Wolffia arrhiza auct., non (L.) Horkel) are almost always regionally uncommon (Dore 1957; Soper 1962; Oldham 2017) and the possibly introduced Papillate Watermeal (Wolffia brasiliensis Weddell) is rare (Thomson 2005). Both W. borealis and W. columbiana are considered rare and of conservation concern in Quebec (Tardif et al. 2005). In addition, populations are increasingly being found beyond Wolffia's traditional northern limit along the southern edge of the Canadian Shield in Ontario (Soper 1962), suggesting ongoing range expansion (Brunton 2018).

Does this change represent climate change? In-

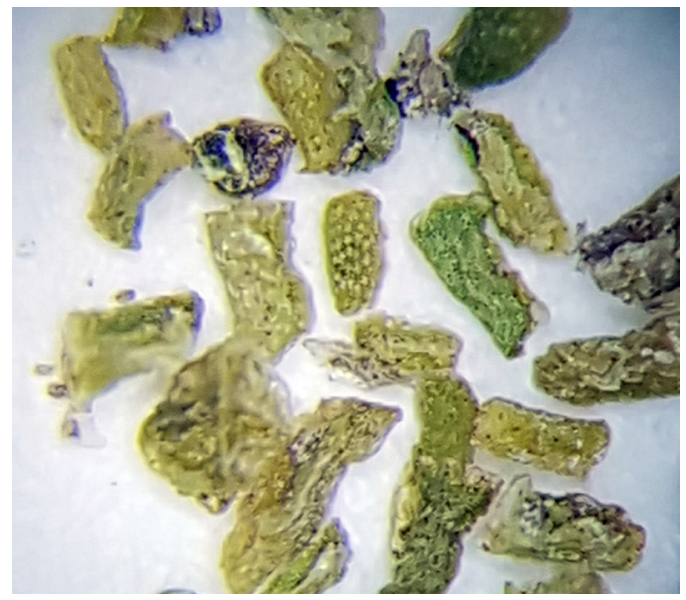

Figure 3. Shrivelled air-dried Northern Duckmeal (Wolffia borealis). 31 July 2011, Peterborough County, Ontario, D.F. Brunton \& K.L. McIntosh 17,896B. Photo: D.F. Brunton.

creased populations of certain waterfowl species? Transportation by human activity? All of the above? That is not clear, but the range of Wolffia unquestionably is enlarging in Canada and new Wolffia occurrences must be recorded with voucher specimens to document this and assess its implications. Accordingly, a practical procedure for producing informative vouchers is an important part of addressing these questions. 
The dry-mounted specimen preparation technique described in this paper is an adaptation of the method described by Brunton (1990) for securing mass samples of even smaller and more fragile megaspores of the aquatic lycophyte Isoetes (quillwort) in a readily examinable state. This new dry-mounting procedure has been used to prepare samples in approximately two dozen Wolffia collections to date. It has resulted in vouchers of superior quality and utility in comparison to most vouchers prepared using traditional methods.

\section{Methods}

A small (5-10 mL) sample of fresh Wolffia plants is placed in a plastic or glass vial with enough of the water-diluted (ca. $75 \%$ of full strength), acid-free glue commonly used in herbarium specimen preparation to maintain the sample free floating. The glue used here was commercially available Weldbond Universal Adhesive (Frank T. Ross \& Sons Ltd., Markham Ontario, Canada). No attempt was made to assess the performance of other commercial brands of adhesive, but it is suspected that any water-soluble white herbarium glue would perform comparably. The sample is left to soak for $\sim 48 \mathrm{~h}$. The container is covered to prevent the glue from drying and solidifying. Because Wolffia plants are exceedingly buoyant, the slurry of plants is stirred periodically (two or three times in the course of the soaking period) to ensure thorough contact with the glue solution.

After about 25-30 h, the colour of the glue solution takes on a distinctively green cast. The Wolffia plants also appear to be less buoyant, floating lower in the solution and remaining submerged slightly longer when stirred. This is interpreted as indicating that the plants have become slightly waterlogged and that the glue has penetrated their tissues.

After $\sim 48 \mathrm{~h}$ the slurry is spread (poured) onto a sheet of plain paper (a heavier gauge, $\mathrm{pH}$ neutral paper is recommended) or directly onto a herbarium sheet (White 100 Percent Rag Bond - neutral pH 20 or $24 \mathrm{lb}$; Herbarium Supply Co., Bozeman, Montana, USA) in as thin a layer as possible and allowed to air dry. Concentrations of plants on the mounting sheet can be thinned by gently passing a dissection needle or probe through them. This must be done immediately after the slurry has been poured, however, as the solution becomes too tacky for smooth manipulation within as little as $10 \mathrm{~min}$. The sample (Figure 4 ) is dry and ready for examination or processing as a herbarium specimen within about $2 \mathrm{~h}$.

\section{Results}

Applying this voucher preparation technique to over 30 samples of native Ontario Wolffia involving

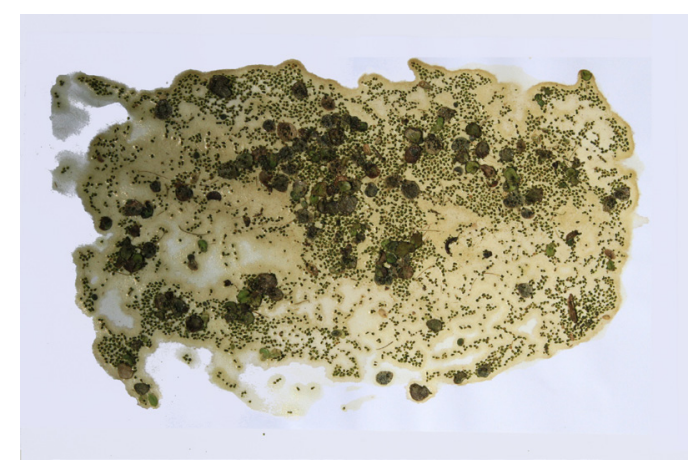

Figure 4. Sample of dried, glue-impregnated Columbia Duckmeal (Wolffia columbiana); larger intermixed plants are Spirodella polyrhiza (L.) Schleiden. 25 August 2017, Renfrew, Renfrew County, Ontario, D.F. Brunton \& K. Fleming 19,783. Photo: D.F. Brunton.

23 separate collections (Appendix 1) has produced encouraging results. Although the dry, glue-impregnated plants are completely deflated and flattened, they have, for the most part, retained their original size, shape, and colour (Figure 5). Some aspects of their morphology remain evident: for example, the punctate (dotted) surface of $W$. borealis is clearly visible in the dried plants.

Rehydrating shrivelled, long-dried herbarium material may also be worthwhile. In the two samples tested, the glue solution did not become as green as it did with fresh material, suggesting that the rehydrating plants do not become as completely saturated. Nonetheless, the rehydrated material was more distinguishable than it would have been if specimens had only been air dried.

It is recommended that collectors making Wolffia vouchers include a packet of air-dried plants ("green dust") prepared in the traditional way as well. This typically indistinguishable air-dried material is potentially useful for chemical and molecular analyses. Ideally, photos of fresh plants should be included in the voucher. When used in combination with glueimpregnated plants, these additional specimen components provide the most complete vouchers possible for multidisciplinary investigations.

More extensive experimentation would refine the technique described here. It may well provide similarly satisfying results, for example, for other aquatic plants that occur in vast numbers of minute individuals, such as duckweed (Lemna), duck-meat (Spirodela), and mud-midget (Wolffiella). A variation on this technique to accommodate larger specimens might also prove useful for the preservation of exceptionally delicate and/or fragile water nymph (Najas), ditchgrass (Ruppia), horned pondweed (Zannichellia), and 


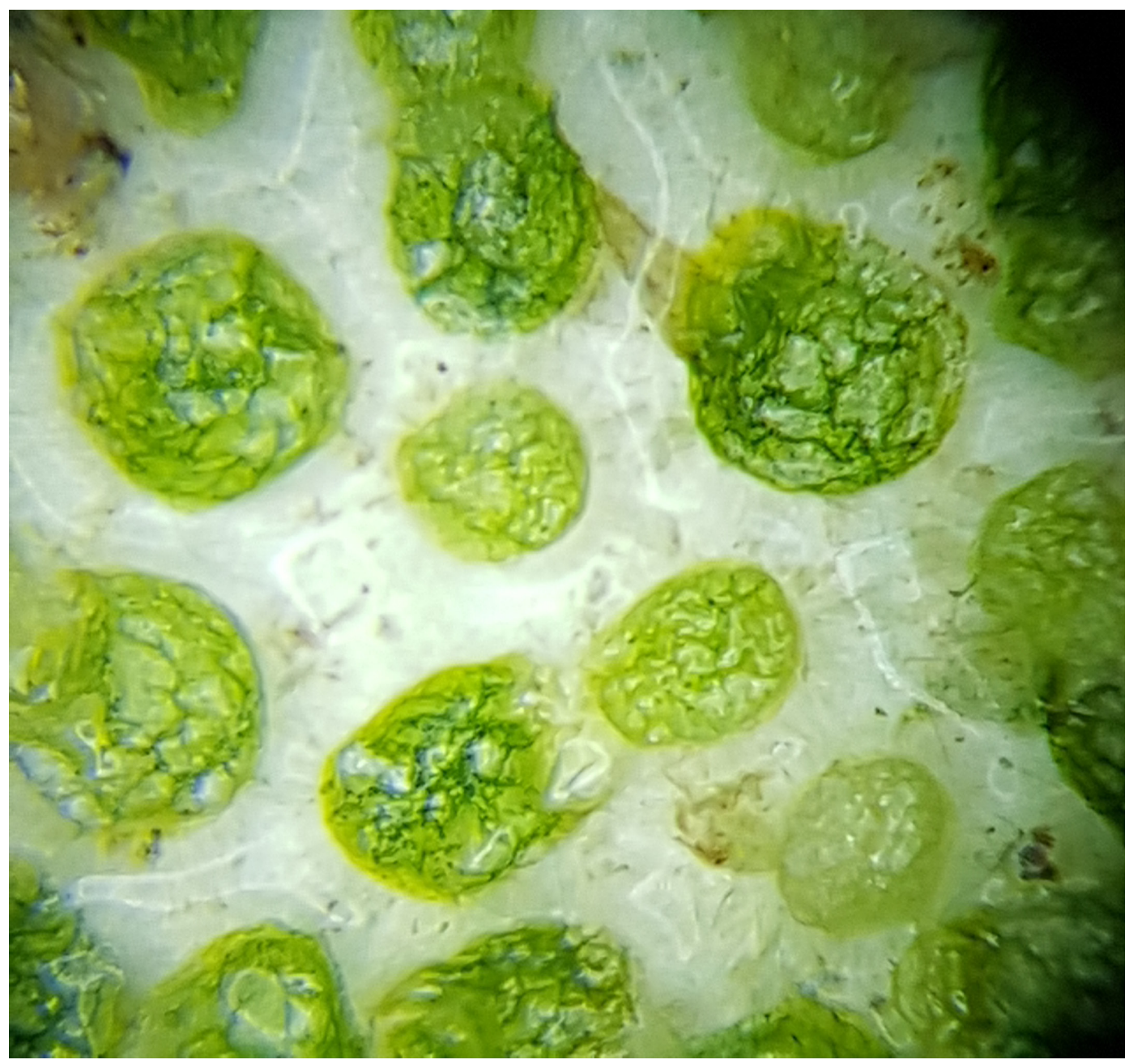

Figure 5. Close-up of glue-impregnated Columbia Duckmeal (Wolffia columbiana) retaining shape and size. 25 August 2017, Renfrew, Renfrew County, Ontario, D.F. Brunton \& K. Fleming 19,783. Photo: D.F. Brunton.

pondweed (Potamogeton and Stuckenia) plants in a more natural form. As currently understood, however, this technique provides a logistically simple, spaceefficient, permanent preservation alternative for making Wolffia vouchers, for which there is an immediate need. The technique has the added benefit of being hazard free for the preparator and posing no curatorial risks to associated herbarium material.

\section{Acknowledgements}

This paper benefited significantly from input by Associate Editor, Paul M. Catling, and reviewers, Bruce Ford, University of Manitoba, Winnipeg, Manitoba, Garret Crow, Calvin College, Grand Rapids, Michigan, and Michael J. Oldham, Ontario Ministry of Natural Resources and Forestry, Peterborough, Ontario. Their valuable comments and observations were based on extensive first-hand field experience with Wolffia. The author was inspired to investigate and collect these curious and challenging aquatic plants in the first place by the enthusiastic encouragement and assistance of the late W.G. (Bill) Dore (1912-1996), then of Agriculture Canada, Ottawa.

\section{Literature Cited}

Brunton, D.F. 1990. A device for the protection of spore samples from Isoetes (Isoetaceae) voucher specimens. Taxon 39: 226-228. https://doi.org/10.2307/1223021

Brunton, D.F. 2018. The changing distribution and extraordinary abundance of Wolffia in Ontario. Field Botanists of Ontario Newsletter 30(2). Accessed 15 March 2019. https://www.researchgate.net/publication/326719302_ Wolffia_in_Ontario_FBO_2018.

Brunton, D.F., and H. Bickerton. 2018. New records for the 
Eastern Mosquito-fern (Azolla cristata: Salviniaceae) in Canada. Canadian Field-Naturalist 132: 350-359. https:// doi.org/10.22621/cfn.v132i4.2033

Crow, G.E., and C.B. Hellquist. 2000. Aquatic and wetland plants of northeastern North America, Volume Two Angiosperms: Monocotyledons. University of Wisconsin Press, Madison, Wisconsin, USA.

Dore, W.G. 1957. Wolffia in Canada. Canadian Field-Naturalist 71: 10-16. Accessed 15 March 2019. https://www. biodiversitylibrary.org/item/89178\#page/22.

Oldham, M.J. 2017. List of the vascular plants of Ontario's Carolinian Zone (Ecoregion 7E). Ontario Ministry of Natural Resources and Forestry, Peterborough. https:// doi. org/10.13140/RG.2.2.34637.33764

Soper, J.H. 1962. Some genera of restricted range in the
Carolinian flora of Canada. Transactions of the Royal Canadian Institute 34 (Part 1): 3-56.

Tardif, B., G. Lavoie, et Y. Lachance. 2005. Atlas de la biodiversité du Québec. Ministère du Développement durable, de l'Environnement et des Parcs, Direction du développement durable, du patrimone écologique et des Parcs, Québec, Canada. Accessed 15 March 2019. https:// tinyurl.com/y3794fcj.

Thomson, E.R. 2005. Papillate Watermeal, Wolffia brasiliensis, in eastern Ontario: an addition to the Flora of Canada. Canadian Field-Naturalist 119: 137-138. https:// doi.org/10.22621/cfn.v119i1.97

Received 20 July 2018

Accepted 25 July 2019

Appendix 1: Wolffia specimens prepared, partly or entirely, using the Weldbond technique. Herbarium acronyms of Thiers (continuously updated).

\section{Wolffia borealis}

Ontario: City of Ottawa, $45.36843^{\circ} \mathrm{N}, 75.79522^{\circ} \mathrm{W}$, west end of Turtle Bay, southwest portion of Mud Lake, Britannia Conservation Area, D.F. Brunton 17,106, 7 September 2007 (DFB);

Ontario: City of Ottawa, $45.33572^{\circ} \mathrm{N}, 75.92777^{\circ} \mathrm{W}$, in Shirley's Brook along south side of Trillium Woods, South March Highlands, Kanata, D.F. Brunton 17,125, 5 October 2007 (DFB);

Ontario: City of Ottawa, $45.39846^{\circ} \mathrm{N}, 75.96812^{\circ} \mathrm{W}$, south end of Constance Lake by inlet of Constance Creek, West Carleton, D.F. Brunton 18,036, 13 August 2011 (CAN, DFB);

Ontario: City of Ottawa, $45.34581^{\circ} \mathrm{N}, 75.86959^{\circ} \mathrm{W}$, abandoned sewage treatment plant $395 \mathrm{~m}$ south southeast of Range Road/Carling Avenue intersection, Nepean, D.F. Brunton 18,913A, 8 October 2014 (WIN, DFB);

Ontario: Frontenac County, $44.27868^{\circ} \mathrm{N}, 76.59344^{\circ} \mathrm{W}$, west side of Collins Creek north side of Creeksford Road, Kingston, D.F. Brunton 18,050A, 24 August 2011 (WIN, DFB);

Ontario: Peterborough County, $44.76643^{\circ} \mathrm{N}, 78.49064^{\circ} \mathrm{W}$, west side of White's Lake Road, north side of Crystal Lake, Galway \& Cavendish Township, D.F. Brunton and K.L. McIntosh 17,986B, 12 July 2011 (DFB);

Ontario: Peterborough County, $44.38742^{\circ} \mathrm{N}, 77.97751^{\circ} \mathrm{W}$, east side of mill pond by outlet, north side of Highway 7, east end of Norwood, Asphodel Township, D.F. Brunton 19,916, 6 September 2017 (DFB).

\section{Wolffia columbiana}

Ontario: City of Ottawa, $45.36843^{\circ} \mathrm{N}, 75.79522^{\circ} \mathrm{W}$, west end of Turtle Bay, southwest portion of Mud Lake, Britannia Conservation Area, D.F. Brunton 17,107, 7 September 2007 (DFB);
Ontario: City of Ottawa, $45.33572^{\circ} \mathrm{N}, 75.92777^{\circ} \mathrm{W}$, in Shirley's Brook along south side of Trillium Woods, South March Highlands, Kanata, D.F. Brunton 17,126, 5 October 2007 (DFB);

Ontario: City of Ottawa, $45.39846^{\circ} \mathrm{N}, 75.96812^{\circ} \mathrm{W}$, south end of Constance Lake by inlet of Constance Creek, West Carleton, D.F. Brunton 18,035, 13 August 2011 (CAN, DFB);

Ontario: City of Ottawa, $45.34581^{\circ} \mathrm{N}, 75.86959^{\circ} \mathrm{W}$, abandoned sewage treatment plant $395 \mathrm{~m}$ southsoutheast of Range Road/Carling Avenue intersection, Nepean, D.F. Brunton 18,913B, 8 October 2014 (WIN, DFB);

Ontario: Frontenac County, $44.27868^{\circ} \mathrm{N}, 76.59344^{\circ} \mathrm{W}$, west side of Collins Creek north side of Creeksford Road, Kingston, D.F. Brunton 18,050B, 24 August 2011 (WIN, DFB);

Ontario: Peterborough County, $44.38742^{\circ} \mathrm{N}, 77.97751^{\circ} \mathrm{W}$, east side of mill pond by outlet, north side of Highway 7, east end of Norwood, Asphodel Township, D.F. Brunton 19,917, 6 September 2017 (DFB);

Ontario: Peterborough County, $44.76643^{\circ} \mathrm{N}, 78.49064^{\circ} \mathrm{W}$, west side of White's Lake Road, north side of Crystal Lake, Galway \& Cavendish Township, D.F. Brunton and K.L. McIntosh 17,986B, 312 July 2011 (WIN, UBC, DFB);

Ontario: Renfrew County, $45.5128^{\circ} \mathrm{N}, 76.7591^{\circ} \mathrm{W}$, $650 \mathrm{~m}$ north of Highway 60 at southeast corner of Clubhouse Lake, west side of Renfrew Golf Club, Horton Geographic Township, D.F. Brunton and K. Fleming 19,873, 27 August 2017 (DFB).

\section{Literature Cited}

Thiers, B. [continuously updated]. Index herbariorum: a global directory of public herbaria and associated staff. New York Botanical Garden's Virtual Herbarium. Accessed 15 March 2019. http://sweetgum.nybg.org/science/ih/. 